V. 8, n.1

Vitória-ES, Jan. - Mar. 2011.

p. 1 - 26 ISSN 1808-2386 DOI: http://dx.doi.org/10.15728/bbr.2011.8.1.1

\title{
An analysis of factors affecting the ethical conduct of microcredit officers
}

\author{
Maurício José Serpa Barros de Moura ${ }^{\dagger}$ \\ World Bank Group \\ Rodrigo de Losso da Silveira Bueno ${ }^{\Omega}$ \\ University of São Paulo - USP \\ Helena Wagner P. Rocha ${ }^{¥}$ \\ University of Maryland \\ Patricia Morilha Muritiba ${ }^{\Psi}$ \\ University Nove de Julho - UNINOVE \\ Sérgio Nunes Muritiba ${ }^{\mathfrak{E}}$ \\ University Nove de Julho - UNINOVE
}

SYNOPSIS: This study examines the ethical conduct of productive microcredit officers, a type of credit that offers small sums to low income customers. In this modality, the microcredit officer performs important work in granting or denying credit in poor communities, and may be exposed to situations of ethical decision-making, such as denying credit to acquaintances in the community where the agent lives. Based on the models of Ferrell, Fraedrich and Ferrell (2009) and Kohlberg (1969) the study examines which factors influence the ethical behavior of this public. The results show that the importance given by the agent to his/her job and the individual sensitivity that denying credit may have, influences his/her ethical behavior. It is recommended that these results be used in the hiring and training of these agents, which can improve ethical decision-making on microcredit.

Keywords: Microcredit; ethics; ethical decision making.

Received in 11/20/2009; revised in 04/20/2010; accept in 06/15/2010; available in 02/04/2011

Corresponding authors*:

\begin{tabular}{lll}
${ }^{\dagger}$ Ph.D. in Public Sector & ${ }^{\Omega}$ Ph.D. in Economics & ${ }^{z}$ Graduated in Business \\
Economics - FGV. & University of Chicago & Administration by the - \\
Link: World Bank Group/ & Link: University of & FGV. \\
Washington. & São Paulo - USP. & Link: Robert H. Smith \\
Address: 1600 South Eads & Address: Av. Prof. & School - University of \\
127-N, Arlington, VA. & Luciano Gualberto, & Maryland. \\
E-mail: & 908. Prédio FEA 2 & Address: 1600 South Eads \\
mauriciojsbm@ @mail.com & Sala Cidade & 127-N, Washington DC, \\
\hline Telephone:(1) 2024031086 & Universitária. São & USA. \\
& Paulo - SP - Brazil - & E-mail: \\
& CEP: 05508-010. & helena.wagner@ gmail.com \\
& E-mail: & Telephone: (11)91234275 \\
& delosso@ usp.br & \\
& Telephone: (11) 3091 \\
& 6070 &
\end{tabular}

$\begin{array}{ll}{ }^{\Psi} \text { PhD in Business } & { }^{t} \mathrm{PhD} \text { in Business } \\ \text { Administration by the USP. } & \text { Administration by the } \\ \text { Link: University Nove de } & \text { Universidade de São } \\ \text { Julho - UNINOVE. } & \text { Paulo - USP. } \\ \text { Address: Rua Trajano Reis } & \text { Link:University Nove de } \\ \text { 185, bloco 4 apto 12, Jd das } & \text { Julho - UNINOVE. } \\ \text { Vertentes. São Paulo - SP - } & \text { Address: Rua Trajano } \\ \text { Brazil. } & \text { Reis, 185, bloco 4 apto } \\ \text { CEP: 05541 030. } & \text { 12. Jd das Vertentes. São } \\ \text { E-mail: } & \text { Paulo - SP - Brazil. } \\ \text { pmorilha@ gmail.com } & \text { CEP: 05541 030. } \\ \text { Telephone:(11) } 85847734 & \begin{array}{l}\text { E-mail: } \\ \text { smuritiba@ @mail.com }\end{array} \\ & \begin{array}{l}\text { Telephone: }(11) 8638 \\ \end{array} \\ & 4083\end{array}$

Editor's note: This paper was accepted by Antonio Lopo Martinez. 


\section{INTRODUCTION}

Recent corporate scandals have brought increased attention to ethics and corporate social responsibility (VALENTINE and FLEISCHMAN, 2008), and questionable practices require leaders to emphasize business ethics and develop programs to prevent wrong behavior in the future. Organizations also have a responsibility or obligation to solve problems of public order (ETHEREDGE, 1999).

Studies on ethics have been conducted with greater intensity after the scandals that shook some big companies like Enron and WorldCom, spread in the late '90s (LINTHICUM, REITENGA and SANCHEZ, 2010). Increasingly, talk about ethics in the workplace has become a thing of relevance, because the behavior of the organization's key employees can have important impacts on company performance.

Most studies on this subject have traditionally focused on the issue of trust (Hosmer, 1995). More recently, there have been studies focusing on the conduct of top management (Chih, and SHEN KANG, 2008, IP, 2008; YEH, SHU and LEE, 2008). Despite senior management carrying a considerable ethical role in companies, other employee groups may also influence the results of their conduct for more or less ethics (FRITZ, and ARNETT CONKEL, 1999; TEETZ and Maniam, 2005; SINGHAPAKDI et al. 2008). In financial institutions that provide micro-credit, one of the group of employees who most influence the ethics of organizations is the group of credit officers (PRIOR and ARGANDOÑA, 2009).

Micro-credit consists in lending low amounts of money to low income persons. This is a type of loan that is growing at the same time that the entrepreneurial activities of small businesses have been growing - such as the creation of small neighborhood businesses, usually in the service sector.

That's what you might call "entrepreneurship by need" - in which low-income people build their small businesses driven by the difficulty of employment in larger companies. Brazil is one of the countries where this type of entrepreneurship occurs more frequently, accompanied also by India. According to the Global Entrepreneurship Monitor (2005), the lack of suitable alternatives in employment and income is the main trigger of small entrepreneurship. However, to build their businesses, the entrepreneur relies on credit, and finds great difficulty in obtaining it in Brazil by conventional ways. Thus arose the productive micro credit, a specific method for small entrepreneurs 
The granting of credit to low income entrepreneurs is hampered by the fact that many have no credit history that can be evaluated by financial institutions. This complicates the evaluation of information, so that many banks end up not lending money to these entrepreneurs (AKERLOF, 1970). In other words: the distinction between good and bad borrowers is prevented.

The way to solve this problem is by hiring an agent with the power to grant credit through visits to the applicants: the credit officer. Among the difficulties of the procedure is the introduction of subjective elements of evaluation, with clear impact on business results. These subjective elements, in turn, involve important ethical issues (MERSLAND and STROM, 2009).

Indeed, to dilute the risks of granting micro-credit, micro finance institutions at the international level, based on the Grameen Bank (YUNUS and JOLIS ,2005) the figure of the microcredit agent is used. It is up to the agent to visit the client, analyze his/her business, collect data about their conditions to receive funding and to use this information, to base the credit granting decision.

For Uranga (1988) the granting of credit is a matter still under development, because there is little research on the topic. Loan officers are exposed to professional ethical dilemmas, such as being offered bribes, kickbacks and even blackmail. It is understood that the concept of the microcredit agent is subject to organizational decision-making involving ethical dilemmas, yet unexplored by the academic literature. Thus, this is a group of professionals whose more or less ethical conduct can impact the organization's results in a visible way

The objective of this study was to examine the ethical decision-making of micro-credit agents so as to identify factors that influence the ethical behavior of these agents

It unfolds in the following research questions:

1. What are the factors that influence the ethical behavior of microcredit loan officers?

2. Are there - and what would they be - the differences between groups of microcredit agents influenced by similar factors?

To answer them, we carried out a survey with 48 microcredit agents of the Unibanco Microinvest in the states of Rio de Janeiro, Sao Paulo, Rio Grande do Sul, Espírito Santo and 
Minas Gerais. This group represents the entire staff of the microfinance institution, thus allowing more accurate results in the studied population.

The ethics of microcredit agents was analyzed based on two theoretical models that complement each other: the Kohlberg model (1969) and the model of Ferrell et al. (2009). These models were chosen directly by treating the ethical decision making within the company, while many of the approaches to theoretical models of business ethics deal holistically with the company without giving specific emphasis to the decisions of officials. Thus, the mentioned models apply directly to the study's objective which is to analyze the ethical decision making of microcredit agents

These questions are justified by the need to evaluate the ethical conduct of microcredit agents. Research with this audience is still new to the literature, particularly in Brazil. Another contribution with this study is to apply the models of Kohlberg (1969) and Ferrell et al. (2009) and shed light on the factors that predispose ethical behavior in organizations.

\section{THEORETICAL REFERENCES}

\subsection{Ethics in organizations}

Ethics includes a sense of honesty and fairness; prudence, respect and being of service to the others; keeping promises; being reliable and building business relationships based on trust and integrity (CACIOPPE, FORSTER e FOX, 2008). Ethics has been defined as the concept of how to behave right and fairly (CARROLL, 1991).

Business ethics, in turn, has been defined as a field that deals with dilemmas that appear in the context of doing business (DE GEORGE, 1999).

This subject can be analyzed from two aspects. The first is the ethics of the organization as a whole, with respect of their actions towards society (Cochran et al.), as in the studies of social responsibility and ethics (BLINDHEIM and LANGHELLE). The other is the ethic of its employees (SHAPIRA-LISHCHINSKY and ROSENBLATT, 2009).

It is common that the ethics of company officials inspires a set of standards that is related in the company's code of ethics (GILLEY, ROBERTSON and MAZUR, 2010). Langlois and Schlegelmilch (1990) as well as Donker, Poff and Zahir (2008) define a code of ethics as a corporate standard that records the company's principles, ethics, rules of conduct, codes of practice or company philosophy with respect to the responsibility with stakeholders, the environment, or other social aspects external to the company. A code of ethics 
demonstrates the company's awareness of ethical issues and indicates how it will deal with such topics.

Ethical decision making in business is a topic of great interest in literature - Ford and Richardson (1994) reviewed the literature in the area and presented a series of theoretical models that can be used to analyze the factors that lead to ethical decision making. Individual factors are, according to the authors, the topics that have received more attention by researchers - many authors seek to relate sex, age, social class, origin and other characteristics of someone's propensity to be more or less ethical

Ferrell et al. (2009) state that individual factors are not the only ones that would lead someone to be more or less ethical. For the authors, ethical behavior is the result of the influence of individual factors over two groups of factors: the seriousness of ethical issues and corporate culture, shown in Figure 1. The model developed by these authors is embraced as the backbone in this study.

This model is specific to ethical decisions in companies where a group work environment is present. With significant frequency, it is assumed that people take ethical decisions in the company the same way they act in family or personal life. However this behavior can vary in the sphere of influence of the organizational environment.

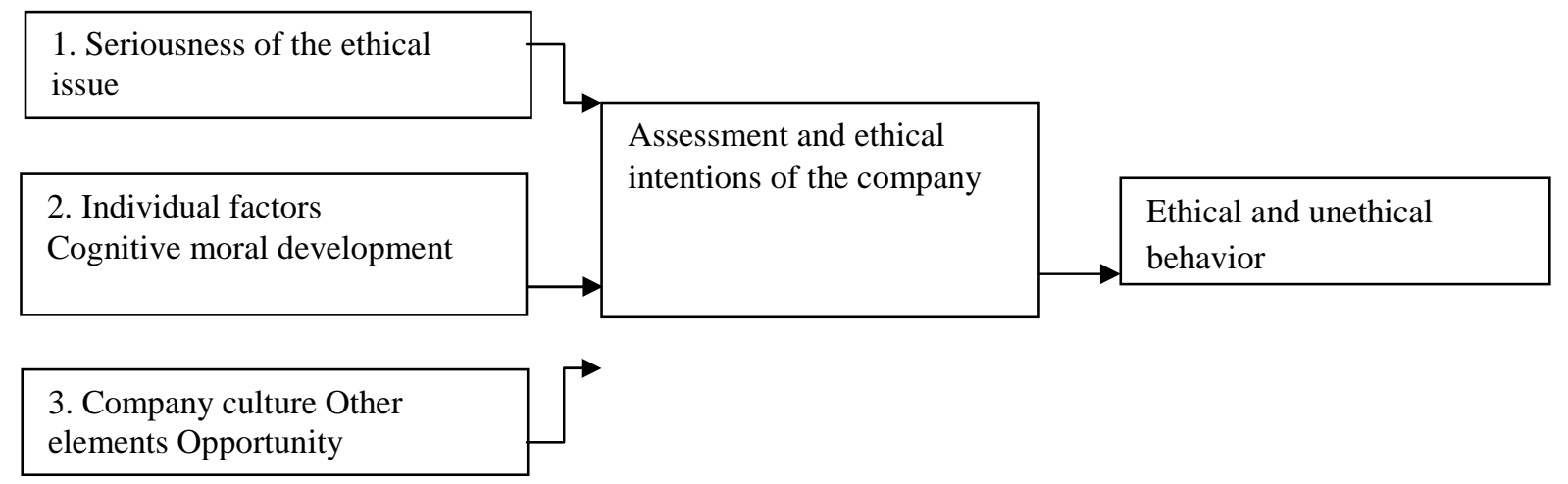

Figure 1: Structural model for ethical decision making in business.

Source: Ferrell, Fraedrich and Ferrell (2009).

According to the model of Ferrell et al. (2009), the seriousness of the ethical issue can be defined as its relevance or importance to the person, work group and/or the company. It assumes personal and temporal character in order to consider values, beliefs, needs and attitudes towards special situations or personal pressures that are felt on a continuous basis, at a certain place or time. The seriousness attached to the issue reflects the ethical sensitivity of the person or work group and begins the process of decision making. 
Company culture can be defined as a set of values, beliefs, goals, standards and ways of solving problems shared by its employees. Within the corporate environment the following items may appear:

- Significant third parties: those who exercise influence over the work, including partners, managers, peers and subordinates.

- Opportunities: describes the conditions that constrain or enable an unethical behavior. They result from situations that affect rewards, whether internal or external.

Still, according to Ferrell, et al. (2009), all the factors described above interact and influence the actions and intentions of employees in a corporate environment, from which the ethical or unethical behavior of those involved results.

Considering the individual factors, these authors assert that the stage of cognitive moral development influences ethical decision making. A classic study on the stages of cognitive development (KOHLBERG, 1969) develops this concept in depth. According to Kohlberg's model (1969), people interpret and react differently to similar ethical situations because they are in different stages of cognitive moral development, which can be

1. The stage of punishment and obedience. At this stage, the individual defines right as literal obedience to rules and authority

2. The stage of the person's purpose and instrumental exchange. The individual defines right as that which serves his/her needs. He/she evaluates behavior based on justice and equity, not only on the authority.

3. The stage of expectations, interpersonal relationships and mutual compliance. At this stage, the individual gives more importance to the welfare of others, to the detriment of self.

4. The stage of maintenance of the social system and consciousness. The individual takes into account duty to society, not just with other people.

5. The stage of more important rights, social contract or utility. The individual is concerned in defending society's fundamental rights, values and legal contracts.

6. The stage of universal ethical principles. The individual believes that right is determined by universal ethical principles, by inalienable rights, by nature and by universal consequences, which should be followed by everybody. 
These six stages represent an evolution in the individual's understanding about what is ethics. In the first, his/her attitude is driven by standards and avoiding possible punishment. In the later stages, his/her attitude would be guided by universal ethical principles.

In this study, the models Ferrell et al. (2009) and Kohlberg (1969) are used to identify the factors that characterize the ethical decision making in microcredit.

\subsection{Ethics and microcredit}

The discussion of ethics includes the problem of financial exclusion of the poorest segments of society of the financial system and access to credit. If access to credit is a key to promote economic development, poverty reduction and improved well-being of all citizens, then one can say, as the Nobel Laureate M Yunus did, that it is a moral necessity to grant credit as a right (HUDON, 2009). But there are arguments that oppose this idea and arguments that support it.

Microfinance institutions play an extremely important role in society because they ensure the survival and growth of micro-businesses which are, in most cases, the only source of credit of these businesses (CAVALCANTE, 2002). Yunus and Jolis (2005, p. 56.) argue that "through microcredit, economic and social development with change in the economic status of people living on the margins of society is enabled."

According to Sen (1988), microcredit is one of the economic tools that help reduce the risk and volatility of income because it provides bases to consolidate the physical and financial assets. The author also warns that the focus of micro-credit is the development of small entrepreneurs and owners of small productive units.

By representing a potential aid for the diversification of income sources and asset acquisition (ROBINSON, 2001; TOSCANO, 2001; PARENTE, 2002), microcredit provides to poor families chances of reducing the risk of becoming even poorer and chances of stepping over the poverty line (RHYNE and CHRISTEN, 1999; WRIGHT, 1999; BARNES, 2001). Lucas (1988) formalizes this idea, arguing that microcredit represents a significant economic contribution to the development of small production units so that the smaller the enterprise, the greater the contribution of capital injection on its marginal productivity.

This type of credit has the potential of innovation in management and marketing adaptation, particularly with respect to small enterprises and sectors related to incipient production and commercial activities (LUCAS, 1988; SCHUMPETER, 1988; CAVALCANTE, 2002). Microcredit, by being less bureaucratic, promotes local economic 
changes as it develops new markets and increases existing ones, strengthens free enterprise, absorbs the workforce and invests in peripheral regions (FELDMAN and AUDSTRECH, 1999).

\subsection{Microcredit in Brazil}

The Central Bank of Brazil (2004, pg. 136) defines microfinance as "the provision of adequate and sustainable financial services to a low-income population, constantly excluded from traditional financial system, with the use of specialized products, processes and management" A microfinance institution is defined by the same source as:

"[...] one that in the context of microfinance, is dedicated to provide small scale credit and differs from other types of loan essentially by the methodology used, quite different from the one adopted for traditional credit operations. It is commonly understood as the main activity of the microfinance sector for the importance it has with public policies in overcoming poverty, generating employment and income [...]" (CENTRAL BANK OF BRAZIL, 2004, pg. 136).

Thus, productive microcredit is characterized by a credit analysis that is personalized and different from traditional credit scoring models used for consumer credit transactions. Serving the needs of the final borrowers of funds is done through the microcredit officer who analyzes the socioeconomic data of customers, guides the management of the business, and estimates its credit needs. The value and the credit terms are defined after the evaluation of the activity and the borrower's indebtedness capacity, the destination of resources, in close dialogue with the borrower. A monitoring of the small entrepreneur's activities is conducted during the contract period for the better use and application of resources as well as for the growth and sustainability of economic activity.

The work of these microcredit agents occurs primarily in slum communities and suburbs. This fact exposes that professional to the structural problems of society, such as lack of sanitation, hygiene, safety and levels of extreme poverty, and subjects the officer to cultivate a closer relationship with customers. These factors together may influence their decision-making which should be based only on objective data

In 2004, it was estimated that there were approximately 16.4 million microenterprises in Brazil, defined according to criteria established by the Central Bank of Brazil (BRAZILIAN INSTITUTE OF GEOGRAPHY AND STATISTICS, 1999). Of this total, the potential demand for loans reached 8.2 million micro enterprises (CHRISTEN, 2001). However, the penetration of microfinance in Brazil is only $2 \%$ of expected demand 
(BRUSKY and FORTUNA, 2002), totaling approximately 245 thousand customers (CENTRAL BANK OF BRAZIL, 2004)

The first Brazilian productive microcredit project was through the UN, in Pernambuco, in 1973 (MOURA and DURKIN, 2003), yet the industry began to thrive only in the 1990s thanks to the monetary stability provided by the Real Plan and yet, has experienced relatively slow growth (GALLAGHER et al., 2002). Given the resistance of traditional financial institutions in expanding their activities in this segment, supply is limited to institutions of local operations, small-scale, such as nonprofit organizations (ROY and CHOWDHURY, 2009)

It is a challenging task for microfinance institutions, to reduce the difficulties of access to credit and structurally change the way the capital is distributed to the population (GRANT, 1999; BRUSKY, 2002; BUETTI, 2002). The extreme dependence on the microcredit agents (MOURA and DURKIN, 2003 can be considered one of the reasons for the timid growth of this sector in Brazil. The process of decision making in this case, as mentioned earlier, is more prone to subjectivity than traditional credit models based on mathematical models, since it provides a greater degree of personal connection between the credit taker and the agent.

In this context of customer proximity and service customization, this article intends to identify the propensity of the occurrence of ethical dilemmas in decision-making process by the agent at the time of credit granting, with this attribute being explored in greater depth in the following chapters.

\section{METHODOLOGICAL ASPECTS}

This study analyzes the characteristics that influence the ethical behavior of microcredit agents, identifying the characteristics common to groups of agents with different ethical behaviors. To this end, a study of quantitative character with microcredit agents of Unibanco Microinvest was performed.

\subsection{Research design and theoretical basis}

Studies of microcredit agents are very rare due to the fact that this is still a recent practice in organizations.

\subsection{Universe and sample}

The sample consisted of 48 microcredit agents of Unibanco Microinvest in the states of Rio de Janeiro, Sao Paulo, Rio Grande do Sul, Espirito Santo and Minas Gerais. It is a 
sample census. In terms of the study's validity and reliability, therefore, these are quite favorable indicators.

Unibanco Microinvest today is the second largest operation of this segment in the country, with approximately $6 \%$ of the market, so it is fairly representative nationwide (UNIBANCO, 2008).

The bank was a pioneer among Brazilian banks, in the operation of guided productive microcredit. Its first experience in the segment occurred through the RioCred NGO in Rio de Janeiro, the result of a partnership between Fininvest, a finance company acquired by Unibanco in 1996, and the Municipality of Rio de Janeiro.

In 2003, with the objective of professionalizing the operation and expanding the supply of microfinance at the national level, the bank, in partnership with the International Finance Corporation (IFC), the financial arm of the World Bank, set up an Entrepreneur Credit Society (WCS) called Unibanco Microinvest. Its main channels of credit supply were the stores of Fininvest, the Makro supermarkets, and the shops of Magazine Luiza. Currently Microinvest Unibanco operates in São Paulo, Rio Grande do Sul, Minas Gerais, Rio de Janeiro and Espirito Santo, totaling 211 outlets.

\subsection{Theoretical basis and development of the instrument for data collection}

The "ethical behavior" construct was implemented based on the models of Ferrell, Fraedrich and Ferrell (2009) and Kohlberg (1969). These two models are complementary, in that the first takes into account the impact of the work environment on the decisions of officials and the second emphasizes the individual aspect.

Thus, the construction of a questionnaire based on the models of both covers a propensity to be ethical which comes from the individual's personal factors and history (KOHLBERG, 1969) as well as the influence that the company has on their choices, guiding and spreading codes conduct, besides other influences such as leadership (FERRELL, FRAEDRICH e FERRELL, 2009).

Therefore, the questionnaire was developed from questions that reflected the corporate culture and individual factors (present in the FERRELL, FRAEDRICK and FERRELL, 2009 model) and the stages of development (present in the KOHLBERG, 1969 study). The questionnaire is attached at the end. The relationship between the questions and the model that inspired them is listed in Chart 1. 


\begin{tabular}{|c|c|c|}
\hline Constructs & Application in Questionnaire & $\begin{array}{l}\text { Study on which it is } \\
\text { based }\end{array}$ \\
\hline $\begin{array}{l}\text { Company } \\
\text { Culture }\end{array}$ & $\begin{array}{l}\text { Objective Questions: } 3,5,6,16,18,19,21,23,26,27,28,29 \text { e } 30 \\
\text { Qualitative Questions: } 35 \\
\text { All questions to the company }(37-46)\end{array}$ & \multirow[t]{2}{*}{ Ferrell et al.(2009) } \\
\hline $\begin{array}{l}\text { Individual } \\
\text { Factors }\end{array}$ & $\begin{array}{l}\text { Objective Questions: } 1,2,4,5,6,22,23,24,25 \\
\text { Qualitative Questions: } 1,2,3 \text { e } 6\end{array}$ & \\
\hline Stage 1 & $\begin{array}{l}\text { Objective Questions: 7,9,10,11, } 19 \\
\text { Qualitative Questions: } 31,33\end{array}$ & \multirow{6}{*}{ Kohlberg (1969) } \\
\hline Stage 2 & $\begin{array}{l}\text { Objective Questions: } 7,9,10,11,12,13,19,30 \\
\text { Qualitative Questions: } 33,36\end{array}$ & \\
\hline Stage 3 & $\begin{array}{l}\text { Objective Questions: 7, 9, 10, 11, 12, 13, 21, 25, } 30 \\
\text { Qualitative Questions: } 33,34\end{array}$ & \\
\hline Stage 4 & $\begin{array}{l}\text { Objective Questions: } 9,12,13,17,21 \\
\text { Qualitative Questions: } 31,32,33,34\end{array}$ & \\
\hline Stage 5 & $\begin{array}{l}\text { Objective Questions: 7, 9, 10, 11, 12, 13, 14, 16, } 19 \\
\text { Qualitative Questions: } 31,33,34\end{array}$ & \\
\hline Stage 6 & $\begin{array}{l}\text { Objective Questions: 10, 11, 12, 13, 17, 21, } 30 \\
\text { Qualitative Questions: } 31,33,34\end{array}$ & \\
\hline
\end{tabular}

CHART 1: IMPLEMENTATION OF THE QUESTIONNAIRE VARIABLES

Source: Drafted by the authors

The data collection instrument consisted of 36 final questions for microcredit agents and 10 questions for the company. The complete instrument is attached.

The 10 questions posed to the company (37-46) were intended to examine qualitatively the company's policies regarding ethics and ethical values in order to disseminate to staff. They were related to the "company culture" construct that integrates the model of Ferrell et al (2009).

The 36 questions were distributed to the agents according to the models of Ferrell et al (2009) and Kohlberg (1969), as shown in Table 1. No numbering sequence was set in order to facilitate the understanding of issues by staff. However, the relationship of each question with the theoretical model is presented in the table. One of the questions aimed to analyze the perceptions of agents regarding the company's culture, a construct in the model of Ferrell et al (op.cit.).

The remaining questions included the analysis of individual agents and the six stages of Kohlberg's model (1969). A block of quantitative questions (10-30), followed by quality questions (31 to 36 ) was made to describe the results. This can be seen in the attached full questionnaire.

Since the data collection instrument was built specifically for this study, it was necessary to pre-test it before use, even if it was built based on already tested models. The next step that was performed, were the interviews with micro-credit officials. They helped to phrase the questions and to understand the agents' daily life. 
Especially in the case of the Kohlberg (1969) model, the questions drafted to identify the development stages needed to be aligned with the microcredit agents' ethical decisions. Thus, the interviews collected information on key environmental influences on their decisions and, consequently, helped analyze the behavior of the agent to these decisions ahead

The interviews were conducted with three agents selected at random from among the 48 agents of the Unibanco Microinvest. We addressed the following themes:

- Access to and understanding of the company's code of ethics;

- Previous experience to the role of microcredit agent;

- Access to various management levels;

- Level and intensity of supervision and punishment;

- Work Routine: main tasks, conditions and difficulties;

- Ethical issues involved in granting credit;

- Reactions / emotions in relation to ethical issues;

- Relevant issues in credit analysis;

- How the microcredit agent's sees the activity carried out by same.

The 36 questions relating to the agents were applied by telephone with the 48 agents. They represent all the Unibanco Microinvest microcredit agents. However questions related to the company were answered by the company's chief executive responsible for microcredit at Fininvest. The questionnaire in this case was applied through a personal interview which was duly recorded and transcribed

We chose to use a dichotomous nominal scale question of the "yes" or "no" type followed by a qualitative question explaining the response (e.g., why?). These qualitative data were used to validate the responses by improving the quality of information obtained since the interviews were conducted by telephone. This method allows to explain any questions not understood by respondents (LAVRAKAS, 1998).

Respondents' personal data were collected and taken into consideration when analyzing the results. Among them are gender, marital status, age, time in the company, income, number of children and home ownership 


\subsection{Data analysis procedures}

The aim of this study, instead of analyzing the questionnaire variables separately, is to identify groups of agents with similar profiles in terms of ethical behavior. After identifying the groups, it purports to answer the question of what are the characteristics of different groups of agents.

Therefore, this article does not present the results of the exploratory and descriptive statistics which were performed, or the content analysis of qualitative questions

The qualitative variables were used to validate the respondents' answers, so as not to allow incorrect understanding of the questions. They were also used in the description of the groups of agents identified.

The groups of agents were identified with the application of the cluster analysis technique. The objective of this technique is to group a set of individuals into homogeneous subgroups, with homogeneity within each cluster and heterogeneity among clusters (HAIR et al., 1998).

To identify individuals who have homogeneity in each group, Euclidean distance - a measure of dissimilarity - was used, where higher values denote lower similarity (LEHMANN, GUPTA and STECKEL, 1998). In the present study Euclidean distance will be applied.

More specifically, the technique described by Ward (HAIR et al., 1998) will be applied. This technique consists of applying the sum of squares of the distances between the two groups performed on all variables to the distance between two clusters. At each stage of the clustering process, the internal sum of squares is minimized over all partitions that can be obtained by the combination of two clusters from the previous stage

The questions that are not qualitative, which required YES or NO objective responses, were transformed in magnitude scales compatible with the dummy values 0 and 1 , respectively, allowing to quantify the distances between clusters. This same technique was used by Dilon (1984).

It is worth noting that the goal of using this methodology is to group the similarities between the 48 microcredit agents interviewed into subgroups according to their responses, and to similar personal characteristics 


\section{PRESENTATION AND ANALYSIS OF RESULTS}

Next are the results lifted from the application of the objective questionnaire. Some responses had a $100 \%$ convergence and characterized important signals about the activity of microcredit agent linked to ethical issues.

Among the survey results, one should note the testimony of microcredit agents who report being coerced by customers who ask for credit, who try to bribe them, offering bribes and even threatening them with violence in an attempt to force them to grant credit. Examples like these were common among respondents, although the interviews were conducted separately with officials from different localities: Rio de Janeiro, Sao Paulo and Porto Alegre.

The staff showed an awareness of the importance of productive microcredit for small businesses, but said that they had difficulty in dealing with denial of funding to people in dire need because of credit policies and control of the risk of default. In these circumstances, instances of the use of emotional appeal and social pressure from the community were recorded, with the prevalence of subjective aspects related to the granting of credit.

All the respondents reported that they understood the company's code of conduct and that they had access to it through internal distribution, in addition to the support of their respective supervisors. The officials also revealed to be aware of the company's monitoring the procedures and criteria for punishment in case of their violation.

Ethical issues related to the activities of agents, the focus of this study, showed up in $85 \%$ of respondents, however, the results of the questionnaires did not come up with evidence of homogeneous character. Because of this, the application of the technique of cluster analysis in clusters becomes applicable, since it consists of a method that helps in understanding the natural structure of a data set.

This technique is widely used in data mining processes for discovering groups and identifying important patterns and distributions (HALKIDI, and BATISTAKIS VAZIRGIANNIS, 2001). In the case of microcredit agents, it was possible to identify patterns of responses and subsequent behavior trends based on questionnaire results, justifying the use of this technique. These results will be presented in subsequent section.

\subsection{Results of the analysis of conglomerates}

The results of the introduction and classification of data in statistical application software (Minitab) are found in Tables 1 and 2. 
Table 1 - Results of multivariate analysis for four clusters

\begin{tabular}{l|c|c|c|c}
\hline & $\begin{array}{c}\text { Number of } \\
\text { observations }\end{array}$ & $\begin{array}{c}\text { Sum of squares within } \\
\text { each cluster }\end{array}$ & $\begin{array}{c}\text { Mean distance from the } \\
\text { central }\end{array}$ & $\begin{array}{c}\text { Maximum distance } \\
\text { from the central }\end{array}$ \\
\hline Cluster 1 & 11 & 594.545 & 6.837 & 12.546 \\
\hline Cluster 2 & 3 & 635.333 & 13.796 & 19.499 \\
\hline Cluster 3 & 18 & 101.556 & 2.208 & 4.058 \\
\hline Cluster 4 & 16 & 177.563 & 2.920 & 5.519 \\
\hline
\end{tabular}

Source: Drafted by the authors.

Table 2 - Distances between the central elements of each cluster

\begin{tabular}{l|c|c|c|c}
\hline & Cluster 1 & Cluster 2 & Cluster 3 & Cluster 4 \\
\hline Cluster 1 & 0 & 53.9839 & 8.2990 & 11.0898 \\
\hline Cluster 2 & 53.9839 & 0 & 58.3145 & 45.0872 \\
\hline Cluster 3 & 8.2990 & 58.3145 & 0 & 18.6366 \\
\hline Cluster 4 & 11.0898 & 45.0872 & 18.6366 & 0 \\
\hline
\end{tabular}

Source: Drafted by the authors.

The graphical representation of the result obtained by the applied technique is presented in graphic 1 below.

\section{Cluster agentes de microcrédito}

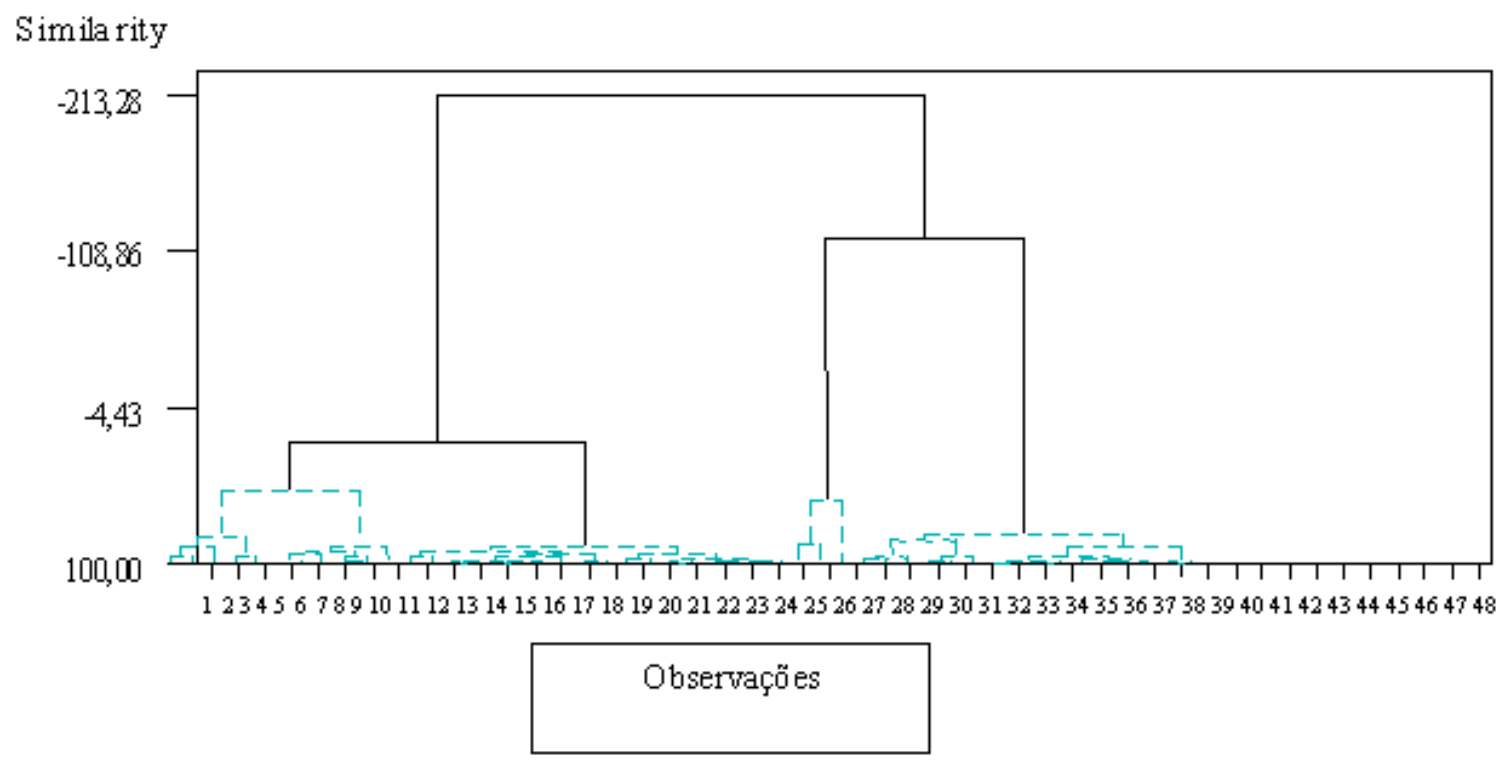

Grapfic 1: Graphical representation of the clusters.

Source: Drafted by the authors.

The graphic above depicts a dendrogram that according to Malhorta (2009), is a graphical representation (graph trees) of the results of a hierarchical procedure in which each object is placed on an axis, the other axis represents the steps in the hierarchical procedure. In this case the horizontal axis represents the microcredit agents, numbered from 1 to 48, the vertical axis, the similarity of the compared elements. 


\subsection{Profiles of the conglomerates}

The agents could be grouped into four clusters according to the similarities found.

Chart 2 summarizes the characteristics of each group.

\begin{tabular}{|c|c|c|c|c|}
\hline Group & 1 & 2 & 3 & 4 \\
\hline Number of Elements & 11 & 3 & 18 & 16 \\
\hline Predominant sex & $\mathrm{M}$ & $\mathrm{M}$ & $\mathrm{F}$ & Mixed \\
\hline Same community? & No & Yes & No & Yes \\
\hline Does family approve? & No & Yes & --- & Yes \\
\hline $\begin{array}{l}\text { Satisfactory } \\
\text { remuneration? }\end{array}$ & No & Yes & No & Yes \\
\hline Description & $\begin{array}{l}\text { Single men } \\
\text { feel very } \\
\text { pressured }\end{array}$ & $\begin{array}{c}\text { Longer } \\
\text { employment time } \\
\text { and accustomed to } \\
\text { the role }\end{array}$ & $\begin{array}{l}\text { Women indifferent } \\
\text { in denying credit }\end{array}$ & $\begin{array}{l}\text { Men and women } \\
\text { susceptible to deny } \\
\text { credit }\end{array}$ \\
\hline \multirow{3}{*}{$\begin{array}{l}\text { Individual factors } \\
\text { (Kohlberg) }\end{array}$} & \multicolumn{4}{|c|}{ Stage 1 - Punishment and obedience } \\
\hline & - & Stages 3 and 4 & - & Stages 3 and 4 \\
\hline & $\begin{array}{l}\text { Easy to lose } \\
\text { Less } \\
\text { commitment }\end{array}$ & - & - & $\begin{array}{c}\text { Make subjective } \\
\text { decisions }\end{array}$ \\
\hline
\end{tabular}

CHART 2: COMPARISON BETWEEN THE CONGLOMERATES OF AGENTS OF MICRO-CREDIT. Source: Drafted by the authors.

The four groups showed different patterns of microcredit agents.

- Group 1: Group 1 could be called the "group with the least commitment." It is comprised mostly of single men, who do not live in the community where they are assessing the credit. Because their families do not approve their job, and they consider the remuneration unsatisfactory, one can assume that this is a group that will not remain long in this position. In terms of individual factors, they are at stage 1 of Kohlberg's model, showing that the members of this group make ethical decisions obeying the organization rules. Remember that this stage of the model is the most incipient in terms of ethical awareness: therefore Group 1 would not be the one most suitable to the function of granting credit.

- Group 2: Group 2 could be called "the veterans". This is a group predominantly made up of men who have longer experience in the function and longer seniority in the company. Their families approve their job and "the veterans" believe their pay to be satisfactory, which signals their permanence in the job. Although they live in the same community in which they grant credit, for having more experience, they can deal best with the pressures - as was shown in the qualitative questions answered by this group. Among its members are those in stages 3 (expectations) and 4 (maintenance of consciousness) of Kohlberg's model. These stages show an awareness of ethics focused on concern for others (stage 3) and society (stage 4). They are thus, loan officers indicated for this function. 
- Group 3: Group 3 could be called "impersonal". It is a group made up mainly of women and their main characteristic is reporting they have no problem in denying credit, even in the environment of pressure and threats reported by respondents. They do not live in the same community and family approval occurred in some cases. Although they can easily handle the pressure, they do not consider their remuneration satisfactory, which may lead to job change. In addition the group features among its members people who are in level 1 of the model - called "punishment and obedience" - that tend to make ethical decisions taking into account the strict rules imposed by the organization, not the social ethical (level 4) or universal ethical (level 5) principles.

- Group 4: Group 4 could be called "susceptible to influence." It is composed of men and women who feel bad in denying credit. Although they are among people at levels 3 and 4 of Kohlberg's model and are therefore more inclined to consider ethical principles, they feel pressured and reported subjective decisions when denying credit. They are therefore the group with the highest ethical risk for ethical institution, although they rank higher in Kohlberg's model of ethical awareness.

When, we compare the groups formed in the analysis, we observed in Table 1 that the group 3 could be described as women indifferent to denying credit. This group, the only one with predominance of females, demonstrated that the greatest ease in dealing with ethical issues related primarily to denying the claim. If we consider a group most likely to make objective decisions then, this would be the third group. However, they are people focused on the organization's policies and that did not show better levels of propensity to the ethics of Kohlberg's model.

The group with the most probable ethical behavior likely would be Group 2, composed mostly of men with more seniority who are accustomed to the role

It can be inferred that the importance of employment for the group is one of the factors that impacts their propensity to ethical decision making. This happens since there is a difference in the propensity among the groups of single men, with less commitment to the job, and the group of married men (longer employment time) and women who are in this job.

A second factor that may be one of the differences in the propensity of ethical decision making is individual sensitivity, of men and women to deny the claim, which could be observed in group 4. 


\subsection{Discussion of results and application of the theoretical model}

The study conducted by the microcredit agents revealed aspects on which it could be possible to apply the structural model of Ferrell et al. (2009:78) for ethical decision making in business, since it was possible to identify the elements that make up the four pillars that support the model structure. The categorization of the sample into four clusters also identified the different stages of cognitive moral development based on Kohlberg's model (1969), where each group of agents is slotted. The application of the Ferrell et al .model (Op.cit.) in this study is depicted in Figure 2.

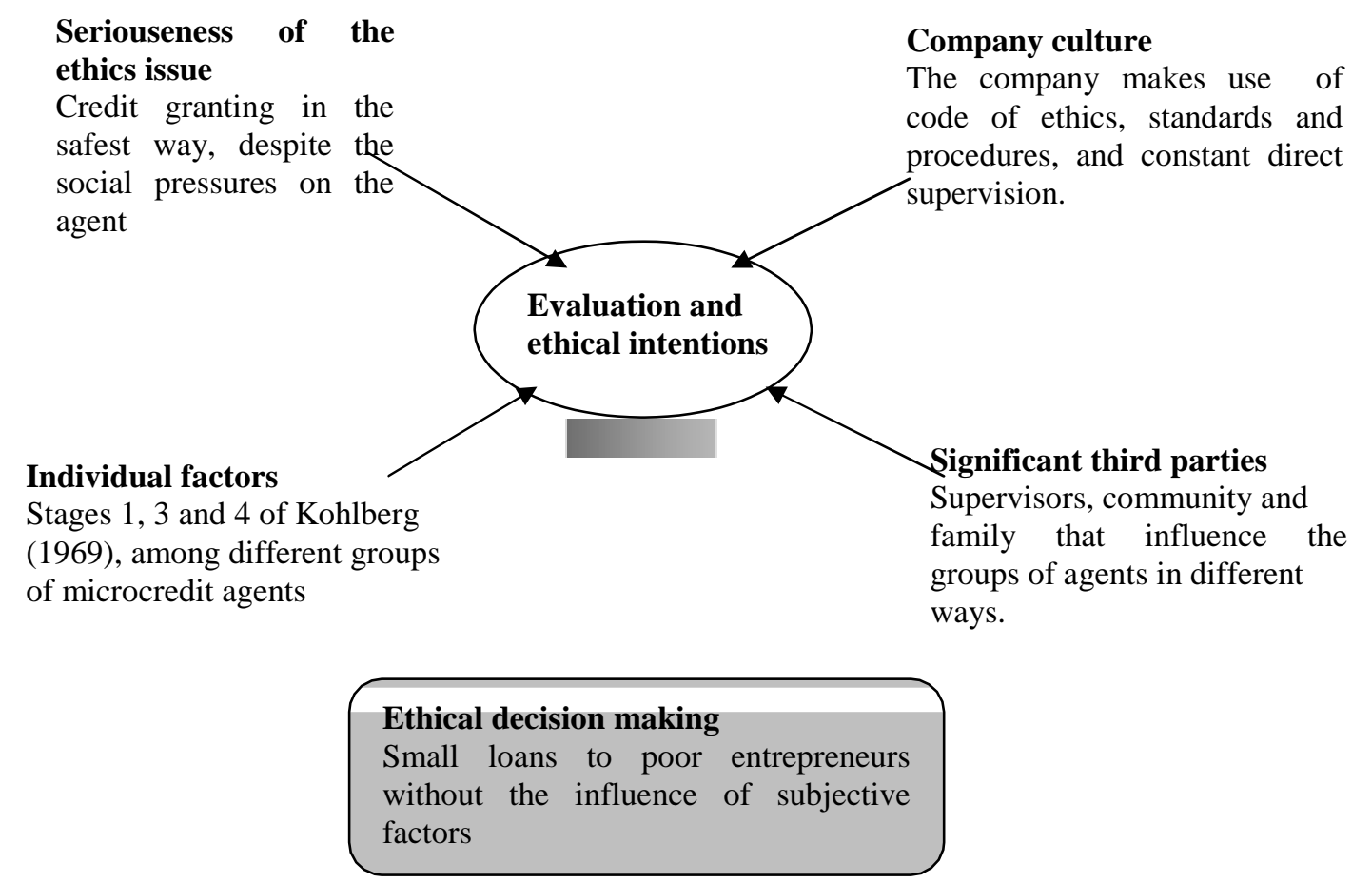

Figure 2: Apllication of the model of Ferrell, Fraedrich and Ferrell (2009) to the microcredit agents.

Source: Drafted by the authors

Figure 2 shows that the severity of the ethics issue, individual factors, company culture and third parties are related to a meaningful evaluation and to ethical intentions, according to the model of Ferrell et al (2009). This in turn influences ethical decision making. It is noteworthy that in the Ferrell model, third parties are considered significant within the company studied. As for the present study, the results showed that an important group for the agents' ethical decision making is their own family. Therefore, we chose to highlight this item, separating it as a fourth pillar influencing ethical intentions.

In analyzing the pillars, one by one, we notice that in the present study, the severity of the ethical issue focuses on aspects that affect the lending agent's decision making. Among 
the issues are: social pressures from customers and from the community for approving the transaction, personal threats, in addition to the actual procedure of credit denial, which excludes people who are really in need in terms of policy criteria and credit risk.

With respect to individual factors, traits identified in groups 2 and 4 allowed them to be classified as belonging to stages of cognitive moral development devised by Kohlberg (1969), constituting the second pillar of the model of Ferrell et al. (2009), related to individual factors. The emphasis on these two groups is justified by the potential of signaling behavior derived from the subjective framework of these groups in stages of development that prioritize the welfare of others and maintaining the social system rather than objective aspects. Applying this assertion to the case of microcredit agents, for belonging to developmental stages 3 and 4, agents are more likely to make a decision regarding the granting of credit based on subjective aspects rather than take into account the financial institution's criteria and rules, thereby presenting a bias towards unethical behavior. However, it is noteworthy also that all groups fall in the first stage of Kohlberg's model (1969), the stage of punishment and obedience. This allows us to assert that the ethical conduct of microcredit agents may be influenced by any administrative measures to be taken by the financial institution.

The fact that the company's culture is represented by rigorous monitoring and by the adherence to standards and procedures, besides the existence of a code of ethics, identified through research, allowed to clarify the company's position regarding the process of decision making and constituting the third pillar that supports the model proposed by Ferrell et al. (2009) concerning the company's culture

Finally, third parties also significantly influence the ethical decision-making agents. It was possible to identify that members of groups 1 and 3, characterized by a more objective approach and adherence to rules, consider the views of people close to them as relevant, both within families and in the workplace. This behavior indicates that agents take into account what Ferrell, et al. (2009) calls significant third parties, able to influence the process of decision making in the organization.

Given the company's cultural aspects of the company and the agents' attitude of the agents regarding significant third parties, one can say that for groups 1 and 3 objective aspects take precedence over subjective ones when making a credit granting decision. 
The ethical behavior of the agent will therefore be the product of the interaction of these four pillars described. It is understood by this that microcredit granting must disregard subjective aspects when making a decision, e.g. to act according to the criteria established by the financial institution for the benefit of all parties - borrower and the credit grantor.

\section{CONCLUSIONS}

This study examined the ethical decision-making of microcredit agents. For this, we developed an analysis tool focused on the reality of these agents' ethics. The study relied on models of: Ferrell et al (2009), aimed at the understanding of ethics in the business environment and Kohlberg (1969), who indicates six evolutionary stages of ethical awareness.

The exploratory analysis of the issues showed that microcredit agents deal with complex situations by analyzing the credit of people from the same social profile and often living in the same poor community. The group of agents who were examined shows uneven levels of cognitive and moral development and shows that this fact will negatively influence the decision making process of micro-credit granting.

The study presented a cluster analysis showing four distinct groups of microcredit agents. The groups showed to have great differences with respect to how they see the granting of credit. Neither group showed a predominance of higher stages of ethical awareness. The importance of ethical standards imposed by the company as a major influencing factor on their decisions was common among them. This might characterize a risk for financial institutions, since the lack of ethics is seen as a risk factor to the financial sustainability of organizations (WEITZNER and DARROCH, 2010).

The ethical issues explicit in the activity of the microcredit agent was found to be directly associated with the granting of credit to people excluded from traditional financial markets, given the exposure to social pressures from customers and community to grant the same. One can add the fact that the agent has to constantly manage credit denial procedures to really needy people in function of the financial institution's policy and credit risk criteria, having his/her decision negatively influenced by subjective aspects.

The application of the model of Ferrell et al. (2009) and Kohlberg's theory (1969) in this article supports the eventual importance of using these concepts in the recruitment, selection, training and development of microcredit agent professionals. The full understanding of situations derived from activities performed by microcredit agents will surely bring 
benefits in the credit quality offered by these institutions, satisfying both the credit supplier and the credit taker.

This paper contributes to the knowledge about productive microcredit by financial institutions so that they recognize the differences in the development of agents and can act for the better management of human resources. Thus, it aims to help consolidate and expand the quality of credit supply to this important segment of the economy

It is recommended therefore that the factors presented as results of the study highlighting the importance of job to the agent and the individual sensitivity when denying credit - be considered in the selection and training of staff as factors that may influence ethical behavior in the organization

As a suggestion to continue this line of research is the application of different ethical models, in order to confirm the validity of the findings of this article and deepen understanding of the results generated by each group presented earlier, showing how ethical treatments can interfere with the quality credit offered.

\section{REFERENCES}

AKERLOF, G. A. The market for" lemons": Quality uncertainty and the market mechanism. The quarterly journal of economics, v. 84, n. 3, p. 488-500, 1970.

BANCO CENTRAL DO BRASIL. Seminário de Microcrédito (Seminar on Microcredit). Goiânia, 2004.

BARNES, C. Microfinance Program Clients and Impact: An Assessment of Zambuko Trust. In: AIMS Paper, 2001, Zimbabwe. Anais. Zimbabwe: AIMS, 2001, p. 18.

BLINDHEIM, B.; LANGHELLE, O. A reinterpretation of the principles of CSR: a pragmatic approach. Corporate Social-Responsibility and Environmental Management, v. 17, n. 2, p. 107, 2010.

BRUSKY, B. Prospecting the FUNDAF Market: an overview of demands, competition, and client satisfaction. Consultative Report, 2002.

BRUSKY, B.; FORTUNA, J. P. Entendendo a demanda para as microfinanças no Brasil. Um estudo qualitativo em duas cidades (Understanding the demand for microfinance in Brazil. A qualitative study in two cities). Rio de Janeiro: PDI / BNDES, 2002.

BUETT, T. Técnicas de Gestão Microfinanceira (Microfinance Management Techniques). Rio de Janeiro: PDI/BNDES, 2002.

CACIOPPE, R.; FORSTER, N.; FOX, M. A Survey of Managers' Perceptions of Corporate Ethics and Social Responsibility and Actions that may Affect Companies' Success. Journal of business ethics, v. 82, n. 3, p. 681-700, 2008. 
CARROLL, A. The pyramid of corporate social responsibility: toward the moral management of organizational stakeholders. Business horizons, v. 34, n. 4, p. 39-48, 1991.

CAVALCANTE, A. B. Programa de microcrédito no nível local: uma alternativa de política pública para ampliar as oportunidades de negócio dos micro e pequenos empreendimentos formais e informais. (Microcredit program at the local level: an alternative public policy to expand business opportunities for micro and small enterprises in the formal and informal) Thesis (Mestrado). Departamento de Economia da EAESP/FGV. São Paulo: EAESP/FGV, 2002.

CHIH, H. L.; SHEN, C. H.; KANG, F. C. Corporate social responsibility, investor protection, and earnings management: Some international evidence. Journal of business ethics, v. 79, n. 1, p. 179-198, 2008.

CHRISTEN, R. P. Commercialization and mission drift. CGAP Occasional Paper, v. 5, 2001.

COCHRAN, L. et al. Developing an Essay Approach to Business Ethics Assessment. Journal of American Academy of Business, v. 15, n. 2, p. 37, 2010.

DE GEORGE, R. T. Business Ethics. New Jersey: Prentice Hall, 1999.

DILLON, W. R.; GOLDSTEIN, M. Multivariate analysis: methods and applications. New York: John Wiley \& Sons, 1984.

DONKER, H.; POFF, D.; ZAHIR, S. Corporate values, codes of ethics, and firm performance: A look at the Canadian context. Journal of business ethics, v. 82, n. 3, p. 527537, 2008.

ETHEREDGE, J. M. The perceived role of ethics and social responsibility: an alternative scale structure. Journal of business ethics, v. 18, n. 1, p. 51-64, 1999.

FELDMAN, M. P.; AUDRETSCH, D. B. Innovation in cities: Science-based diversity, specialization and localized competition. European Economic Review, v. 43, n. 2, p. 409429, 1999.

FERRELL, O. C.; FRAEDRICH, J.; FERRELL, L. Business ethics: ethical decision making and cases. South-Western Publications, 2009.

FORD, R. C.; RICHARDSON, W. D. Ethical decision making: A review of the empirical literature. Journal of business ethics, v. 13, n. 3, p. 205-221, 1994.

FRITZ, J. M. H.; ARNETT, R. C.; CONKEL, M. Organizational ethical standards and organizational commitment. Journal of business ethics, v. 20, n. 4, p. 289, 1999.

GALLAGHER, E. et al. Ethical dilemmas in home care case management. Journal of healthcare management, v. 47, n. 2, p. 85, 2002.

GILLEY, K.; ROBERTSON, C.; MAZUR, T. The bottom-line benefits of ethics code commitment. Business horizons, v. 53, n. 1, p. 31, 2010. 
GLOBAL ENTERPRENEURSHIP MONITOR. Empreendedorismo no Brasil 2005: relatório executivo. (Entrepreneurship in Brazil 2005: Executive Report) Curitiba: IBQP, 2005.

GRANT, W. Marketing in Microfinance Institutions: The State of the Practice. Development Alternatives International, 1999.

HAIR, J. F. et al. Multivariate data analysis. Upper Saddle River: Prentice-Hall, 1998.

HALKIDI, M.; BATISTAKIS, Y.; VAZIRGIANNIS, M. On clustering validation techniques. Journal of Intelligent Information Systems, v. 17, n. 2, p. 107-145, 2001.

HOSMER, L. T. Trust: The connecting link between organizational theory and philosophical ethics. Academy of Management Review, v. 20, n. 2, p. 379-403, 1995.

HUDON, M. Should access to credit be a right? Journal of business ethics, v. 84, n. 1, p. 17 28, 2009.

INSTITUTO BRASILEIRO DE GEOGRAFIA E ESTATÍSTICA (BRAZILIAN INSTITUTE OF GEOGRAPHY AND STATISTICS). IBGE Regional Accounts. São Paulo, 1999.

IP, P. K. Corporate social responsibility and crony capitalism in Taiwan. Journal of business ethics, v. 79, n. 1, p. 167-177, 2008.

KOHLBERG, L. Stage and sequence: the cognitive-developmental approach to socialization. In: GOSLIN, D. A. (Ed.). Handbook of socialization theory and research. Chicago: Rand McNally, 1969.

LANGLOIS, C. C.; SCHLEGELMILCH, B. B. Do corporate codes of ethics reflect national character? Evidence from Europe and the United States. Journal of International Business Studies, v. 21, n. 4, 1990.

LAVRAKAS, P. J. Methods for sampling and interviewing in telephone surveys. In: BICKMAN, L. e ROG, D. J. (Ed.). Handbook of applied social research methods. Thousand Oaks: Sage Publications, 1998.

LEHMANN, D. R.; GUPTA, S.; STECKEL, J. H. Marketing research. Addison-Wesley Reading, 1998.

LINTHICUM, C.; REITENGA, A.; SANCHEZ, J. Social responsibility and corporate reputation: The case of the Arthur Andersen Enron audit failure. Journal of Accounting and Public Policy, v. 29, n. 2, p. 160, 2010.

LUCAS, R. On the mechanism of Economics Development. Journal of Monetary Economics, v. 22, n. 1, 1988.

MALHOTRA, N. K. Marketing research an applied orientation. Pearson, 2009. 
MANIAM, B.; TEETZ, H. Current realities of ethical issues in corporate america: how does ethics effect the financial arena. Journal of Legal, Ethical and Regulatory Issues, v. 8, n. $1 / 2$, p. 83, 2005.

MERSLAND, R.; STRØM, R. Performance and governance in microfinance institutions. Journal of Banking \& Finance, v. 33, n. 4, p. 662, 2009.

MOURA, M. J. S. B.; DURKIN, S. An empirical analysis of the Bank of Northeast Experience. University of Chicago Social Sciences Magazine, 2003.

PARENTE, S. Microcredit as a Financial Market Mechanism to Reduce Poverty. Tese (Mestrado). da Massachussets Institute of Technology. Cambridge: Massachussets Institute of Technology, 2002.

PRIOR, F.; ARGANDOÑA, A. Credit accessibility and corporate social responsibility in financial institutions: the case of microfinance. Business Ethics, v. 18, n. 4, p. 349, 2009.

RHYNE, E.; CHRISTEN, R. P. Microfinance enters the marketplace. Washington DC: USAID, 1999.

ROBINSON, M. S. The microfinance revolution: Sustainable finance for the poor. Washington DC: World Bank Publications, 2001.

ROY, J.; CHOWDHURY, P. Public-private partnerships in micro-finance: Should NGO involvement be restricted? Journal of Development Economics, v. 90, n. 2, p. 200, 2009.

SCHUMPETER, J. A. Teoria do Desenvolvimento Econômico: uma investigação sobre lucros, capital, juro e ciclo econômico (Theory of Economic Development: an inquiry into profits, capital, interest and business cycle). São Paulo: Nova Cultural, 1988.

SEN, A. Freedom of choice: concept and content. European Economic Review, v. 32, n. 2-3, p. 269-294, 1988.

SHAPIRA-LISHCHINSKY, O.; ROSENBLATT, Z. Perceptions of Organizational Ethics as Predictors of Work Absence: A Test of Alternative Absence Measures. Journal of business ethics, v. 88, n. 4, p. 717, 2009.

SINGHAPAKDI, A. et al. Antecedents and Consequences of Perceived Importance of Ethics in Marketing Situations: A Study of Thai Businesspeople. Journal of business ethics, v. 81, n. 4, p. 887, 2008.

TOSCANO, I. Microcrédito: uma filosofia de mudança (Microcredit: a philosophy of change). São Paulo: FEDERAÇÃO DE APOIO AOS PEQUENOS EMPREENDIMENTOS (FENAPE), 2001.

UNIBANCO. Unibanco Microinvest. 2008. Available at: < http://www.unibanco.com.br/vste/_sus/por/oqf/pvo/mic/index.asp >.

URANGA, D. Navigating The Grey Zone: Ethics In Credit Management. Business Credit, v. 90, n. 5, p. 49, 1988. 
VALENTINE, S.; FLEISCHMAN, G. Professional Ethical Standards, Corporate Social Responsibility, and the Perceived Role of Ethics and Social Responsibility. Journal of business ethics, v. 82, n. 3, p. 657-666, 2008.

WEITZNER, D.; DARROCH, J. The Limits of Strategic Rationality: Ethics, Enterprise Risk Management, and Governance. Journal of business ethics, v. 92, n. 3, p. 361-372, 2010.

WRIGHT, G. A. N. Examining the impact of microfinance services-increasing income or reducing poverty? Small Enterprise Development, v. 10, n. 1, p. 38-47, 1999.

YEH, Y. H.; LEE, T. S.; SHU, P. G. The Agency Problems Embedded in Firm's Equity Investment. Journal of business ethics, v. 79, n. 1, p. 151-166, 2008.

YUNUS, M.; JOLIS, A. O banqueiro dos pobres: a revolução do microcrédito que ajudou os pobres de dezenas de países (The banker to the poor: the microcredit revolution that has helped dozens of poor countries). São Paulo: Ática, 2005.

Annex: list of questions of the data collection instrument

\begin{tabular}{|c|c|c|}
\hline No. & Question & Scale \\
\hline 1 & Do you have your own house? & Yes/No \\
\hline 2 & Do you live with your family? & Yes/No \\
\hline 3 & Did Fininvest deliver any code of conduct / behavior to you? & Yes/No \\
\hline 4 & Did you ever work with anything like what you do today at Fininvest? & Yes/No \\
\hline 5 & When you need to talk to your boss, supervisor or manager, do you find it difficult? & Yes/No \\
\hline 6 & Have you ever needed / wanted to give suggestions to your boss? & Yes/No \\
\hline 7 & Does someone oversee your activities and results? & Yes/No \\
\hline 8 & How do you reach your customers? & $\begin{array}{l}\text { On foot, } \\
\text { subway, bus, } \\
\text { private car }\end{array}$ \\
\hline 9 & $\begin{array}{l}\text { Have you suffered threats / bribes / blackmail / bribes because of the decision taken / that } \\
\text { would be taken on credit? }\end{array}$ & Yes/No \\
\hline 10 & $\begin{array}{l}\text { Do you know that your decision whether to give credit to the customer can change his } \\
\text { life? }\end{array}$ & Yes/No \\
\hline 11 & $\begin{array}{l}\text { Have you already had to deny credit to someone who really needed? How did you feel in } \\
\text { this situation? }\end{array}$ & Yes/No \\
\hline 12 & $\begin{array}{l}\text { In the decision whether or not the credit to the customer, do you consider the customer's } \\
\text { life story? }\end{array}$ & Yes/No \\
\hline 13 & Have you been through situations where the customer calls for the thrill to get credit? & $\begin{array}{l}\text { Yes/No } \\
\text { Which? }\end{array}$ \\
\hline 14 & Do you feel pressured by Fininvest because of their decision making? & Yes/No \\
\hline 15 & $\begin{array}{l}\text { At work, have you ever been through unexpected situations that could put you at risk? } \\
\text { Example: shootings, heavy rains, police blockades and drug traffickers. }\end{array}$ & $\begin{array}{l}\text { Yes/No } \\
\text { Which? }\end{array}$ \\
\hline 16 & Do you feel rewarded financially? & Yes/No \\
\hline 17 & Do you think customers understand or appreciate your activity as a credit agent? & Yes/No \\
\hline 18 & $\begin{array}{l}\text { Do you receive commissions or compensation by the amount of Fininvest contracts } \\
\text { closed? }\end{array}$ & Yes/No \\
\hline 19 & $\begin{array}{l}\text { Have you ever been punished by Fininvest for having taken some wrong decision to } \\
\text { grant credit? }\end{array}$ & Yes/No \\
\hline 20 & $\begin{array}{l}\text { Do you think the way you make decisions in your personal life changed after you have } \\
\text { received guidance on how to make decisions by Fininvest? }\end{array}$ & Yes/No \\
\hline 21 & $\begin{array}{l}\text { What do you think the activity of Fininvest - give credit to people who have no proof of } \\
\text { income? }\end{array}$ & $\begin{array}{l}\text { Very good } \\
\text { Good } \\
\text { Whatever } \\
\text { Bad }\end{array}$ \\
\hline 22 & Is this your only job? & Yes/No \\
\hline 23 & Is your salary at Fininvest sufficient for your personal /family expenses? & Yes/No \\
\hline
\end{tabular}




\begin{tabular}{|l|l|l|}
\hline 24 & Do you consider your jobs as temporary Fininvest? & Yes/No \\
\hline 25 & Do you have any career dreams? & Yes/No \\
\hline 26 & Do you think your physically activity is strenuous? & Yes/No \\
\hline 27 & Does your routine allow leisure time? & Yes/No \\
\hline 28 & During work can you take breaks for rest, food? & Yes/No \\
\hline 29 & $\begin{array}{l}\text { Does the company organize events (outside the work environment) that allow integration } \\
\text { / social interaction, bringing together family and coworkers? }\end{array}$ & Yes/No \\
\hline 30 & $\begin{array}{l}\text { Do you identify with what Fininvest finds important in the workplace and how it deals } \\
\text { with customers? }\end{array}$ & Yes/No \\
\hline 31 & What does your activity as credit agent means for you? & Qualitative \\
\hline 32 & Does your family know what you do as a loan officer? What do they think about it? & Qualitative \\
\hline 33 & $\begin{array}{l}\text { The way you make decisions at work is the same way you make decisions in the } \\
\text { home/life /family? }\end{array}$ & Qualitative \\
\hline 34 & Why did you choose to work at Fininvest? & Qualitative \\
\hline 35 & $\begin{array}{l}\text { Did Fininvest invest in your courses or personal development? If yes, select the options } \\
\text { below on how it happened }\end{array}$ & Qualitative \\
\hline 36 & What is the agent's perception about the company hierarchy? & Qualitative \\
\hline
\end{tabular}

\section{Questions to the company}

\begin{tabular}{|l|l|l|}
\hline 37 & $\begin{array}{l}\text { Is Fininvest able to identify ethical problems in the activities undertaken by credit staff? } \\
\text { Does the agent know that it can be subjected to serious ethical questions? }\end{array}$ & Qualitative \\
\hline 38 & $\begin{array}{l}\text { Does the company educate/prepare employees to ethically sensitive situations? How? } \\
\text { Courses, training, lectures, awareness of the work environment, does it expect own } \\
\text { initiative? How often? Is there any monitoring? }\end{array}$ & Qualitative \\
\hline 39 & $\begin{array}{l}\text { When loan officers are hired are the EQ and level of maturity of the hired person taken } \\
\text { in account ? How did you evaluate this? (Interview, the agent's life history, examination } \\
\text { / tests, simulations, analysis of ambitions, dreams, personal concerns) }\end{array}$ & Qualitative \\
\hline 40 & $\begin{array}{l}\text { Does the company teach, transmit its values? Are the values the ones from Fininvest or } \\
\text { Unibanco? Are the values, mission and concepts very different? }\end{array}$ & Qualitative \\
\hline 41 & What is the relevance of the attitude developed by the loan officer to the company? & Qualitative \\
\hline 42 & $\begin{array}{l}\text { Is it clear to the loan officer that he/she is going to grant credit to “entrepreneurs" and } \\
\text { that this can benefit society? }\end{array}$ & Qualitative \\
\hline 43 & Was the loan officer given an option in which community to work? & Qualitative \\
\hline 44 & $\begin{array}{l}\text { Does the company encourage or tolerate unethical attitudes? Is there punishment for } \\
\text { unethical behavior? }\end{array}$ & Qualitative \\
\hline 45 & Is there control or compliance with standards? & Qualitative \\
\hline 46 & $\begin{array}{l}\text { Do agents have to give some kind of reporting or accountability periodically? Are } \\
\text { agents' suggestions and opinions received by the company? }\end{array}$ & Qualitative \\
\hline
\end{tabular}

